\title{
Journey from isolation
}

\author{
Author: \\ Wim A. Dreyer ${ }^{1}$ \\ Affiliation: \\ ${ }^{1}$ Department of Church \\ History, University of \\ Pretoria, South Africa \\ Correspondence to: \\ Wim Dreyer \\ email: \\ wim.dreyer@up.ac.za \\ Postal address: \\ 19 Elephant Street, \\ Monument Park, Pretoria \\ 0001, South Africa \\ Dates: \\ Received: 25 May 2010 \\ Accepted: 01 Sept. 2010 \\ Published: 07 June 2011 \\ How to cite this article: \\ Dreyer, W.A., 2011, \\ 'Journey from isolation', \\ HTS Teologiese Studies/ \\ Theological Studies 67(1), \\ Art. \#869, 9 pages. DOI: \\ 10.4102/hts.v67i1.869
}

(C) 2011. The Authors. Licensee: OpenJournals Publishing. This work is licensed under the Creative Commons Attribution License.
Since the Ottawa Consultation in 1982, the relationship between the Nederduitsch Hervormde Kerk van Afrika (NHKA) and the World Alliance of Reformed Churches (WARC) was nonexistent. In the NHKA it became progressively clear that it would be impossible to travel the road of faith alone. This article examined the factors which contributed to the growing isolation of the NHKA, especially nationalism, a particularistic ecclesiology and the rejection of Apartheid by international ecumenical bodies. It also reflected on efforts of the NHKA to return to the international ecumenical movement.

\section{Introduction}

The South African debate on ecumenical relations, since 1954, is dominated by the issue of racism. Connected to this is the political system of pluralism or racial segregation, better known as Apartheid. Because of the support churches in South Africa gave to racial segregation and the division of churches along racial lines, their membership of international ecumenical bodies was suspended.

In this article the story of the Nederduitsch Hervormde Kerk van Afrika (NHKA), her support of Afrikaner nationalism and Apartheid as well as the journey from international isolation is told.

\section{Different views on Apartheid}

Apartheid has its roots in the way Dutch and British colonial authorities exercised their political power. Fundamental to colonial rule was the political concept of pluralism (see Murray 1962).

For instance, the British colonial rule held the central power in hand, whilst leaving local chiefs and traditional leaders the freedom to exercise limited jurisdiction over their tribe. This policy was called indirect rule (Van Rensburg 1974:214). It created a system of central (White or colonial) government on national level, with indigenous (Black) leaders and structures limited to certain functions and certain areas. For more than two centuries, this model of segregation and limited political power to Black people became the excepted norm in many British colonies (including South Africa).

Concurrently with British colonial rule, White (Afrikaner) and Black Nationalism raised its head, inciting extreme patriotic and nationalistic fervour.

During the 20th century, indirect rule provided a model of segregation and pluralism, culminating in Apartheid. The first formal set of laws based on racial segregation and the establishment of self-governing Black (ethnic) reservations, was developed under leadership of prime minister J.B.M. Hertzog and the Afrikaner nationalist government in 1926 (Giliomee 2004:409). Segregation facilitated the self-determination and political freedom of the Afrikaner people in areas which were regarded as 'White areas'. The system of ethnic segregation became known as Apartheid, an Afrikaans word which means to be apart.

Apartheid is a theoretical concept which is difficult to define (Botha 1986:13). It is more than a political system based on the concepts of pluralism and indirect rule. It is intrinsically interwoven with an early pioneering way of life, with a strong emphasis on survival in Africa. In the 20th century it became progressively more ideologically driven, building on the nationalistic sentiments of political freedom and self-determination. In the euphoria of Afrikaner Nationalism, the Afrikaans speaking churches fell into the trap of giving Apartheid a religious foundation. This type of volksteologie, to my mind, has a lot of commonality with other better known liberation theologies.

Apartheid was not only a political theory, but also a practical system of government which led to violence and structural injustice. It is quite clear that those defending Apartheid (including 
churches) very often focused their defence on the political theory of freedom and self-determination, whilst the critics of Apartheid pointed out that the theory could not be removed from its practical implementation and the injustice it brought forth.

The leadership of the NHKA gradually realised that race relations would become the major issue in South Africa, not only in politics but also in the church. As early as 1929, the editor of the Hervormer, newspaper of the NHKA, started writing about great conflicts which in future will be racially motivated. Articles that appeared in the official publications and magazines reflect a growing concern with race relations (for an extensive overview of printed articles see Van Wyk 1978).

Not only did the NHKA speak and write about racial issues, but slowly a theology developed in which racial segregation was presented as a decent and normal way of existence.

The church leadership needed, at several stages, to send pastoral letters to congregations explaining and defending the NHKA's position on racial segregation.

A few examples can be mentioned in terms of how the NHKA thought about racial segregation (Apartheid) and how perceptions changed over time:

In 1973, the Commission of the General Assembly sent out a pastoral letter to all the congregations in which it gave an extensive exposition of Article III, which limited membership of the NHKA to White people (NHKA 1973:107-119). In the pastoral letter it is reiterated that the NHKA rejects any form of integration in church and state. Apartheid is described as the only honest and Christian policy that would prevent the domination of one group by another (translated from Afrikaans by W.A. Dreyer).

In the pastoral letter, segregation in church and state is presented as in line with general Scriptural principles. It states: 'The church wishes to state emphatically that these measures (i.e. segregation in church and state) are not temporary, but are permanent and unchangeable and founded on Scriptural principles' (NHKA 1973:111).

These general principles were, in short, the following:

- the existence of different nations is part of God's creation

- the development of an Afrikaner nation in Africa is part of Divine providence

- the policy of segregation protects not only White people but also Black people from domination and exploitation.

It is further reiterated that Article III of the Church Order wishes to encourage the preaching of the gospel not only to Afrikaners in their own language, but also to Black people in their language. The NHKA saw itself as an ethnic church (volkskerk), called to preach the Gospel to the Afrikaner nation, not because the Afrikaner nation is more important than any other, but because the NHKA came into existence within the history and life of the Afrikaner nation.
Unity between churches of different races is not to be found in structural unity, but in Christ.

The NHKA supported mission work under all the nations in South Africa (Mt 28). The development of a separate Black church was seen as in line with acceptable missiological practices, in terms of churches becoming indigenous without unnecessary cultural transference. Because of language differences, it was obvious that separate church services would be held for different race groups.

It is clear that the 1973 pastoral letter tried to give a theological and ethical basis to segregation and per implication to Apartheid as political system.

In 1990, the General Commission sent out another pastoral letter called Church and Politics, which, in 26 pages, discussed the church's view on the state, government, race relations, human rights, education, communism, theology of liberation and the economy (NHKA 1990).

In comparison to the 1973 document, a fundamental shift was obvious in the sense that no mention was made of Article III or segregation. What remained was the focus on the NHKA as an ethnic church (volkskerk) as well as the issues of language and culture. At the same time, mission work amongst other nations was emphasised as an important calling.

In the same chapter any form of racism is rejected as contrary to the Gospel of Jesus Christ. On page 12 it is stated:

The Church rejects as incompatible with Christian responsibility any humiliating measures or acts between people ... as well as the over emphasis of own dignity, honour or interests at the expense of the happiness and prosperity of other people.

(Church and Politics 1990)

The maintenance of own identity should be done in such a way, that it would not constitute racism.

Although this careful formulation did not refer to Apartheid as such, the implications were clear: Racism in church and state is unacceptable. The Church would maintain a critical distance in its relation to the Afrikaner nation, but still minister to it in solidarity. It was obvious that the uncritical acceptance of segregation of the earlier years made way for a more dialectical approach which could be described as a critical solidarity.

In 2001, during the 65th General Assembly, another shift was made. The issue of a confession of guilt regarding the NHKA's role in Apartheid was discussed. Many delegates were vehemently opposed to any form of confession. In the end, the Assembly reached a compromise and adopted a resolution which reads:

The Nederduitsch Hervormde Kerk wishes to call for a balanced, Biblical evaluation of the present and the past of our country's history. This balanced evaluation ... includes that the Nederduitsch Hervormde Kerk took notice of atrocities committed under the auspices of the Apartheid policy, even by this Church's own members. For that, the Church expresses its sorrow and remorse before God. 
The Nederduitsch Hervormde Kerk calls for a confession of guilt before God and fellow man and to a new life where the love of God determines our conduct towards all people. This General Church Assembly is deeply aware of our Church's sin, sin to its fullest terrifying extent as the Bible depicts it: Hate, animosity, rebellion, lovelessness, disobedience, and negligence towards God and fellow man.

The Church therefore calls upon all functionaries and members of the Church, but also all other Churches and people, to sincerely confess their guilt before God and towards each other, continually in public worship and in our personal lives, for everything that was wrong in the eyes of the Lord and in our lives. This confession of guilt must be supported by a new life without any animosity or hate.

The Nederduitsch Hervormde Kerk calls upon all people, the government and citizens, to have faith in Jesus Christ, the only Mediator between God and the people, the Redeemer and Saviour of the world.

The Church knows that no other prospect of or hope for real peace, true redemption and total fulfilment exists on earth for mankind besides that given by God's message of salvation in Jesus Christ. From the Word, the Church knows the mystery of God's love, and the Church wishes to remain with strength and conviction the bearer of that mystery to the world, in spite of the pain caused by the Church's own guilt and disobedience to God.

The Church believes in God's forgiveness of all our sins and guilt on account of Jesus Christ's sacrifice on the cross. To know Him and to experience the power of His resurrection is the only way in which the evil within us and around us can be overcome. The Church therefore rejects the process that perpetuates the accusations about the guilt of the past. We should never put ahead of us that which God, in Christ, has put behind us. Let us rather with a Biblical attitude free ourselves from what lies behind us and reach out to what lies ahead. The Church prays for the divine grace to persevere in its only mission, to faithfully bring God's message to the world: In Christ's name, accept the reconciliation with God that He brought to pass.

(NHKA 2001)

The 2001 resolution on Apartheid seems inadequate, because it only mentions the implementation of Apartheid and individual acts of racism and violence. It neither refers to Apartheid as a political system built on the political principles of pluralism and racial segregation, nor does it refer to the NHKA's acceptance that different races are fundamentally irreconcilable.

However, in terms of the historical development, the 2001 resolution constituted a clear shift away from the legitimising of Apartheid (1973), to a position of neutrality (1990), to a position of criticism and a limited confession of guilt (2001).

The issue was again raised at the General Assemblies of 2004, 2007 and 2010, to which we will refer later. At this point it is enough to mention that the 2010 General Assembly of the NHKA rejected Apartheid as contrary to the gospel of Jesus Christ. The 2010 resolution ended a 60 year debate on racial segregation and Apartheid.

\section{Racial clauses in the church order}

The Afrikaans speaking churches in South Africa exist as independent reformed churches since 1824. It was in that year that the British Governor of the Cape Colony, for the first time, gave permission to the Dutch (Afrikaans) speaking congregations to meet in a General Assembly (Algemene Kerkvergadering). This first General Assembly on African soil convened on 02 November 1824 in Cape Town.

On the agenda of the first General Assembly was the adoption of a Church Order for the reformed church in South Africa. The Algemeen Reglement voor het Bestuur der Nederduitsche Hervormde Kerk in Zuid-Afrika was the result (Pont 1991:216).

Barely 12 years later, in 1836, a number of Afrikaners became dissatisfied with British rule. There were several reasons for this dissatisfaction:

- the economic recession

- safety on the borders of the Cape Colony and the continuing Xhosa wars

- too little compensation when the slaves received emancipation

- the forced usage of English in public life, schools and churches.

All these factors convinced some Afrikaners to search for political freedom outside the British sphere of influence. Many of the emigrants were filled with the republican ideals of the French and Dutch Patriots of the time, opposed to any form of monarchy (see Beyers 1967). The result was a mass emigration to the north, beyond the borders of the Cape Colony. This migration became known as the Great Trek, or in Afrikaans Groot Trek.

Less than 3000 pioneers settled north of the Vaal River. In 1852, Great Britain granted political independence to these settlers with the signing of the Sand River Convention and the official establishment of the Zuid-Afrikaansche Republiek (ZAR).

On 05 March 1858, the parliament of the ZAR passed a Constitution which included several articles on the church (see Volksraad van die ZAR Grondwet, SA Archives Tvl. No. 3/496). These articles stated clearly that the Nederduitsch Hervormde Kerk would be the officially recognised church in the ZAR and as such would function as a national church - a church for the people (volkskerk).

The ZAR Constitution was strongly influenced by the French, Dutch and American revolutionary politics of the time (see Du Plessis 1968), which focused on the people and the will of the people. It was extremely anti-British and anti-monarchy, as well as pro-republican and pro-people. Every article of the Constitution starts with the clause 'Het volk wil ...' [The people will/want].

The ZAR Constitution stated clearly that the indigenous tribes would have no equal rights with the White settlers, 
neither in church nor in state (Article 9). It meant that Black people would be ministered to by missionaries at mission posts, whilst the NHKA would serve only White settlers. The NHKA became, through the ZAR Constitution, legally bound to serve only white people. The church followed the social order of the time without any objections. Through the Constitution a situation developed in the ZAR where church, government and people (volk) became an organically interwoven body. For many years there were to be no separation between church and state. Politics was religion, and vice versa. It became a way of life.

During the brutal Second Anglo-Boer War (1899-1902), the ZAR lost its independence and the Afrikaners became British subjects once again. The war all but destroyed the NHKA. Less than ten thousand members of the NHKA survived the war. The war resulted in the destruction of approximately $80 \%$ of all farmsteads that had to be rebuilt after the war. The death of approximately $25 \%$ of the population in British concentration camps and on the battle field decimated the church membership. Most of the church buildings were burned by British troops. Only three ministers remained to serve in the NHKA.

As a result, the NHKA had very little feeling for the British imperialist government, but retained an organic relationship with the Afrikaner people. In a certain sense, the Afrikaans churches (both the NHKA and the NGK) was seen to be carrying forward the ideals of Afrikaner nationalism and freedom, which was lost on the battle field and in the political arena. These sentiments had a profound influence on the future developments in South Africa, more specifically in the Afrikaans churches.

The new political dispensation, with British rule, made changes to the Church Order necessary. In 1904 a new Church Order (NHKA 1904) was adopted, in which - for the first time - an article appeared (Article II) which stated that only White people could be members of the NHKA. It is clear, with the end of the ZAR and its Constitution the Church Order adopted an article with limitations on membership. This was continued in the revised Church Orders of 1925 and 1937.

The period after the Second Anglo-Boer War was marked by fierce anti-British sentiments and growing Afrikaner nationalism and idealism. Nationalist Afrikaners, under British domination, spent a lot of time and energy on creating a social order and society (in Africa) where they could maintain their own language, culture and religion. The result was separate living areas, separate amenities, separate schools and separate churches.

In 1951 the NHKA adopted a new Church Order (NHKA 1951), in which a new approach was evident. Article III of the Church Order stipulated that the Church would create indigenous churches, because the NHKA deemed it the best way of adhering to the great commission of Christ in Matthew 28. Article III was maintained until 1997.

The theological basis for this formulation in the Church Order was found in Dutch theology which supported the idea of a national church (volkskerk). In the Dutch theology two, or rather three, distinct schools of thought existed (Van Ruler 1958:3): The first was the 'theocratic' volkskerk concept as was found in the vision of Hoedemaker, Van Ruler and Wormser; the 'apostolic' volkskerk as was put forward by Kraemer; thirdly those who did not want anything to do with a volkskerk, like Kuyper and later Hoekendijk.

In the South African debate, the most important theologians quoted in support of a volkskerk, was J. Calvin, P.J. Hoedemaker, A.A. Van Ruler, H. Berkhof and H.J. Langman (Botha 1989:3-29). In Van Ruler's terms 'volkskerk' is understood as a church, which in all her actions and in all her words remains involved in the life of the people, letting the light of the Word shine upon society, so that government - in governing the people - can walk in this light (Botha 1989:27).

The volkskerk built on the ideal that the church should reach every corner of Afrikaner society with the gospel. Education, family life, government institutions and public life should be Christianised. The idea of such an ethnic church appealed to the Afrikaners in their search for identity and their nationalistic struggle for political freedom. It became the dominant paradigm in the discussion of Article III and limitation of membership of the church to White people.

In the Netherlands, a national volkskerk could not be perceived as racist, whilst in South Africa a nationalistic or ethnic church would immediately appear racist, especially with a clause in the Church Order which limited membership to White people only. In the Netherlands, the volkskerk was never limited to White people. The Dutch volkskerk theology could not be transplanted without painful distortion.

For 35 years (1959-1994) the levels of conflict and racial tension increased in South Africa. The African National Congress started the armed struggle with civil unrest and military action, whilst reprisals and attacks by the Police and South African Defence Force escalated. With time and in this context, the debate in the church became more and more ideologically driven. It became almost impossible for the church to discuss racism, Article III and Apartheid without ending in a political debate.

It was only in 1997, after 8 years of preparation, that the NHKA adopted a new Church Order (NHKA 1997). In this Church Order race was no longer mentioned in terms of membership. Article III with its racial clauses was dropped and replaced with Ordinance 4, which articulates the NHKA's choice to be a volkskerk, a church which ministers to the Afrikaner people as well as all other people. It meant (theoretically) that anybody, irrespective of race or nationality, could become a member of the NHKA.

\section{Ecumenical relations}

It speaks for itself that the racial clauses in the Church Order and the NHKA position on Apartheid would affect its relationship with international ecumenical bodies. 
In 1951, a mission conference was organised in Bloemfontein. A representative of the World Council of Churches (WCC), J.C. Hoekendijk, attended the conference. He presented a report to W.A. Visser $t^{\prime}$ Hooft, secretary-general of the WCC who decided to visit South Africa in 1952. Since then, the international ecumenical world had taken a more direct interest in race relations, Apartheid and the segregated churches of South Africa.

Initially the Afrikaans churches participated wholeheartedly in the ecumenical movement. The NHKA representatives to the 1954 WCC Assembly at Evanston joined the discussions with enthusiasm. This would shortly change.

The Second Assembly of the WCC declared in Evanston its conviction that any form of segregation based on race, colour or ethnic origin is contrary to the gospel, and is incompatible with the Christian doctrine of man and with the nature of the Church of Christ. The Assembly urged Churches within its membership to renounce all forms of segregation or discrimination and to work for their abolition within their own life and within society (Berkhof 1954:577-578). The South African delegates were alone in their defence of Apartheid. This started a process which was marked by conflict and strained relations, culminating in total isolation.

All the Reformed and some Pentecostal churches in South Africa, in one way or another, defended Apartheid. English churches were not outspoken defenders of Apartheid, but in reality practiced segregation.

A break in relations came with the Cottesloe Consultation, held in Johannesburg in December 1960. The direct stimulus for the Cottesloe Consultation was the riots at Sharpeville (March 1960). Approximately 10000 Black people marched on the police station at Sharpeville to protest the carrying of passes. Amidst growing tension the police fired more than 700 shots, wounding 180 people and killing 69 people. This resulted in a flood of protest from churches and governments all over the world.

During the Cottesloe Consultation churches were asked to condemn Apartheid as contrary to Christian principles and unworkable in practice. The Afrikaans speaking churches were not prepared to condemn Apartheid outright and openly. The result was a middle of the road declaration, which asked for justice, a living wage, abolition of job reservation and so on.

The NHKA disassociated itself from the Consultation. This forced the NGK to react similarly, in fear of losing many members to the NHKA.

Shortly thereafter, the NHKA met in a General Assembly and on 20 March 1961 it decided to terminate its membership of the WCC. The NHKA regarded the actions of the WCC as based on humanistic ideology and its support of revolution as double morality.
At the same time, Dr H.F. Verwoerd, the prime minister, led South Africa from the Commonwealth, and after a referendum, declared the country a republic. The fires of nationalism and republican idealism burned high. The Afrikaner republic, which was destroyed during the Second Anglo-Boer War and lost with the treaty of Vereeniging on 31 May 1902, was restored on 31 May 1961. Against this background, it became virtually impossible for the Afrikaans churches to disassociate with Apartheid.

Some Afrikaners viewed the international ecumenical bodies as the enemy, part of a communist master plan to dominate the world. This perception of the ecumenical bodies that came to the fore in the context of the 1960 Cold War and Afrikaner politics was clearly ideologically driven.

In 1982, the process repeated itself with the NHKA's suspension from World Alliance of Reformed Churches by the General Council of WARC in Ottawa, and its subsequent resignation from WARC.

The Ottawa meeting opened in a dramatic manner, when some of the South African delegates refused to take part in Holy Communion with the delegates of the Dutch Reformed Churches, due to their refusal (in South Africa) to allow Black people to celebrate Holy Communion in White congregations. The negative sentiments continued during the first week's plenary sessions, Bible studies and open hearing on South Africa.

The themes of the Ottawa meeting were: 'The covenant and the mission of the kingdom; the power of grace and the graceless powers; the theatre of glory and a threatened creation's hope'. In all the discussions, South Africa and racial discrimination featured prominently.

In the end, the General Council adopted a statement which condemned racism and Apartheid (Resolution on racism and South Africa).

The statement showed that Jesus Christ had affirmed human dignity and that the Gospel demanded a community of believers that transcended all barriers of race and that racism was a form of idolatry; it states:

Without denying the universality of racist sin, we must call special attention to South Africa. Apartheid (or Separate Development) in South Africa today poses a unique challenge to the church, especially the churches in the reformed tradition. The white Afrikaans churches of South Africa through the years have worked out in considerable detail both the policy itself and the theological and moral justification for the system. Apartheid ... therefore is a pseudo-religious ideology as well as a political policy. It depends to a large extent on this moral and theological justification. The division of Reformed churches in South Africa on the basis of race and colour is being defended as a faithful interpretation of the will of God and of the Reformed understanding of the church in the world ... The General Council of the WARC in Ottawa declares: The promises of God for his world and for his church are in direct contradiction to the 
Apartheid ideals and practices ... Therefore the General council declares that this situation constitutes a status confessionis for our churches, which means that we regard this as an issue on which it is not possible to differ without seriously jeopardizing the integrity of our common confession as Reformed churches ... We declare with Black Reformed Christians of South Africa that Apartheid is a sin, and that the moral and theological justification of it is a travesty of the Gospel and ... , a theological heresy.

(See WARC Ottawa Resolution)

The General Council further pointed out that the system of Apartheid created havoc by large scale deportation and forced removals, destroying families and community life. It constituted nothing less than oppression and injustice. As a result, the Ottawa Consultation declared a status confessionis with regard to Apartheid. Blei (1994) interprets it as follows:

Literally, status confessionis means a situation of confessing, a situation in which the confession of Jesus Christ is at stake. As it was stated in the Ottawa resolution itself: Declaring that a situation constitutes a status confessionis means that we regard this as an issue on which it is not possible to differ without seriously jeopardizing the integrity of our common confession. The Seoul general council dealt more elaborately with the status confessionis issue as such. 'Any declaration of a status confessionis stems from the conviction that the integrity of the gospel is in danger ...' It demands of the church a clear, unequivocal decision for the truth of the gospel, and identifies the opposite opinion, teaching or practice as heretical.

(Blei 1994)

The Ottawa Consultation also passed a resolution to suspend the membership of the NHKA and the NGK, and would only reconsider the reinstatement of membership if the Afrikaans if Black Christians would no longer be excluded from church services and Holy Communion; concrete support is given to those who suffered under Apartheid and an unequivocal synodic resolution rejecting Apartheid as sinful.

The NHKA General Commission met on 17 September 1982 and decided to resign its membership from the WARC. In a letter the secretary of the WARC, dated 06 October 1982, the General Commission not only withdrew the NHKA from the WARC but delivered a scathing attack on the WARC.

\section{Resolutions by the Nederduitsch Hervormde Kerk van Afrika on ecumenical relations}

The NHKA General Assembly, over the years, passed several resolutions on ecumenical relations. A summary of some are presented here in an English version. The original resolutions are all in Afrikaans and can be found in the minutes of the various General Assemblies. These minutes are available in the NHKA Church Archive in Pretoria.

After 15 years of international ecumenical isolation, the General Assembly of the NHKA adopted a new Church Order in 1997 (NHKA 1997), which states clearly in Ordinance 6 the view of the NHKA on ecumenical relations:

The Church, as manifestation of the one, holy, catholic and Christian Church, keeps up ecumenical relations with other churches.
The Church gives expression to its fundamental and essential unity with other churches in the Reformed tradition by

- maintaining good relations

- consulting each other on faith, teaching and obedience to God

- supporting each other

- cooperation in ecumenical bodies and councils

- celebrating in joint worship

- the Church maintains consultations with churches and groups from other ecclesiastical traditions by explaining and defending its teachings, coming to a better understanding and support of each other

- the Church is assisted by committee, which maintain consultations, do research and advise official assemblies.

(Ordinance 6)

The General Assembly of 2001 adopted the following resolution:

- To take a positive stance to a more actual connection with ecumenical bodies namely WARC, the REC and the SACC;

- The Ecumenical Board take up talks with the SACC;

- To start corresponding with WARC;

- To have talks with churches that are members of WARC and the REC ;

- To send observers to the SACC.

- To take up correspondence with the Reformed Church in the Netherlands.

(General Assembly 2001)

The General assembly of 2004 took the resolution to further ecumenical contact by:

- Applying for the reinstatement of its membership of WARC and the REC.

- Applying for observer status of the SACC.

- To take up relations with the Uniting Church of Australia.

(General assembly 2004)

During the 2004 meeting of WARC in Accra the NHKA sent two observers to Ghana with the instruction to explore membership of WARC and during 2005 a delegation of five members attended the Synod meeting of the REC in Utrecht during which the NHKA applied for membership that was unanimously accepted.

\section{More recent developments}

Against the background of the resolutions passed by the General Assembly of the NHKA as well as the articles of the Church Order, the General Commission of the NHKA started a process of rebuilding ecumenical relations. The re-evaluation of ecumenical relations led to an expansion of ecumenical activities by the NHKA. In recent years, several developments took place in terms of establishing ecumenical relations:

- The NHKA maintains a close relationship with the Maranatha Reformed Church of Christ.

- The NHKA is a founder member of the Tussen Kerklike Raad, which involves the NGK, Gereformeerde Kerke van Suid-Afrika as well as the NHKA. 
- The NHKA is a founder member of the Konvent van Reformatoriese Kerke van Suid-Afrika.

- The NHKA established correspondence with the Presbyterian Church of South Africa, and is involved with the PBSA and the NGK in theological training at the University of Pretoria.

- Correspondence and mutual visits were established with the Reformed Church of Australia.

- The NHKA became a full member of the Reformed Ecumenical Synod in 2005.

- Various contacts were built up with the Presbyterian churches of Uganda, Ghana, the Lutheran Church of South Africa as well as the Roman Catholic Church.

The single most important development was the request of the NHKA to the WARC Executive, that its membership of this body should be reinstated. The WARC Executive responded positively and a letter the NHKA received in $2005^{1}$ the Executive Committee of WARC resolved to:

- begin a two year process with the expectation that a recommendation can be made on the readmission of the NHK to the next Executive Committee in 2007

- in the process, the Executive Committee advises the NHK to undertake the following steps within two years:

- NHKA needs to demonstrate to the churches in South Africa and the world that NHKA fully and completely rejects apartheid as sin and the theological and biblical justification of it as heresy. This will include a full public recognition of the sinfulness of apartheid and its biblical and theological justification that were used to support it as heretical. In this light we would like to see the full text of the adopted resolution from the NHKA General Assembly on the heresies of Apartheid.

- The NHKA needs to strengthen ecumenical ties among churches in South Africa and begin the reconciliation process at the local and national levels. If NHKA is still not a member church of the South African Council of Churches, then WARC would like to see NHKA taking steps in becoming a member of SACC.

- The NHKA needs to demonstrate steps in becoming a key player in contributing to the transformation of South African churches by bringing racial integration and harmony. A good example is for NHK to make public commitment in church union with black churches with which it once belonged together.

- The executive committee authorizes a visit to NHKA and its key partners during the twelve months before the next Executive Committee meeting in 2007.

\section{The 68th General Assembly (2007)}

The process, as set out in letter of the WARC, was implemented in the course of 2006. A delegation from the WARC, including representatives from South African churches, had

1.The complete correspondence between the WARC Secretary-General and the Commission of the General Church Assembly of the NHKA is available at the Archives of the NHKA in Pretoria. long discussions with several churches in South Africa, but especially the General Commission of the NHKA.

During the discussions the delegations of the WARC and the NHKA agreed that the NHKA had met the first two conditions of the Ottawa resolution. The outstanding issue was the question of a public confession on Apartheid.

The previous Commission of the General Assembly agreed to put these additional conditions to the 68th General Assembly and formulated different proposals to this effect.

The Church was informed of the history behind the proposals and the need for accepting the proposals in various meetings and conferences, facilitated by the Commission of the General Assembly. The following Joint Resolution was presented to the General Assembly:

Both the World Alliance of Reformed Churches (WARC) and the Nederduitsch Hervormde Kerk van Afrika (NHKA) express their desire to restore the membership of the NHKA after their withdrawal from the Alliance in 1982 following their suspension by the 21st General Council, and to see the NHKA warmly welcomed back into active membership with full privileges in the family of WARC.

1. As part of this action, the Alliance reaffirms its repudiation of any theological justification of apartheid as a matter of status confessionis for the churches inasmuch as such a theological justification is a travesty of the gospel and in its persistent disobedience to the Word of God, a theological heresy. ${ }^{2}$

2. As part of this action, the NHKA through its General Assembly, meeting in 2007, within the framework of the decision of WARC (paragraph 1 above), assures the Alliance that it rejects apartheid as wrong and sinful not simply in its effects and operations but also in its fundamental nature.

3. WARC pledges to continue to work pastorally with the NHKA and other churches in Southern Africa in the process of unity and reconciliation.

4. Upon visible concrete changes expressed clearly in all NHKA instruments of governance and intent for church unity called for in the WARC team visit of June 2006 by the NHKA General Assembly of 2007, and after the WARC Executive Committee of 2007 is fully satisfied that is the case, the NHKA will be re-admitted into WARC

2.For the purposes of this resolution, the word 'heresy' is to be interpreted in terms of the following extract from the pastoral letter to the Dutch Reformed Church from the Alliance: 'There has been some confusion over what the Ottawa General Council meant when it called the theological justification of apartheid "heresy". This term should not be understood to imply "excommunication". WARC is not a church but a fellowship of churches; therefore, it possess no authority to excommunicate. WARC does not presume to judge whether those who in the past taught the rightness of apartheid will be damned or saved. Reformed people leave the dead to the merciful judgment of God. WARC intended to convey its profound concern fo the responsibility of the living church to teach faithfully the gospel of Jesus Christ, the responsibility of the living church to teach faithfully the gospel of Jesus Christ, for the teachers of the church stand under God's judgment, accountable for thei stewardship of the mysteries of God. "Heresy" is persistent and deliberate teaching of false doctrine after the error has been pointed out by the wider church. This term conveys WARC's conviction that the theological justification if apartheid was no simply an "error" in stating doctrine or a disagreement in matters where there is freedom to disagree but rather a fundamental perversion and deformation of the heart of the gospel.' 
Both WARC and the NHKA give thanks to God for this act of reconciliation and pray that it will strengthen the joint witness of all Reformed Churches both in Southern Africa and throughout the world.

(NHKA 2007:178)

The Commission of the General Commission, in a letter to the WARC Executive (dated September 2006) inter alia undertook the following:

The Commission of the General Assembly would like to reiterate the importance of our ecumenical relations with other Reformed Churches. We are convinced that it is necessary for the NHKA, in our search for the Truth, to not only to listen to the Holy Scripture but also to the voices of other churches. We recognise the importance of these voices for our understanding of issues such as Apartheid.

The General Commission respect the delegation's interpretation that the NHKA did not yet meet the three resolutions adopted by the Ottawa Conference for the Church's readmission to the WARC. However, the General Commission interpreted the recent events and resolutions passed by the General Assembly differently, as became clear in the opening address of the Moderator. In spite of different interpretations, the Commission will present this matter to the 68th General Assembly for discussion. The exact wording, as proposed by the WARC delegation, will be part of the agenda and the General Assembly will take its decision based on that wording.

The Commission took notice of the view expressed by the WARC delegation, that the confession of guilt as professed by the $66^{\text {th }}$ General Assembly was inadequate. As a confession of guilt is an extremely important matter to the NHKA, the Commission will present the confession, which formed the basis of the confession of guilt professed by the NG Church and formulated by the WARC, unaltered to the 68th General Assembly.

(Letter from the General Commission to WARC, September 2006)

Parts of this letter were also included in the Agenda of the General Assembly 2007 (pp. 179-180). After extensive discussions, the Commission of the General Assembly formulated the following proposal to the General Assembly (NHKA 2007:181, translated into English):

The 68th General Assembly concludes that Apartheid cannot be justified and that we reject Apartheid because it:

- is contradictory to the gospel of Jesus Christ

- is based on the idea that people cannot be reconciled

- sanctions injustice

- scars the image of God in people.

We confirm the theological character of this resolution. (NHKA 2007:181 [translated into English])

The proposal was vigorously debated and eventually dismissed by a very slim majority of 262 votes against 260 . The General Assembly, however, requested the General
Commission to continue with discussions with the Executive Committee of the WARC. The agenda of these discussions were the conditions which the WARC had set for the readmittance of the NHKA. The 69th General Assembly would then take a final decision on the matter.

During the 68th General Assembly, the Commission of the General Assembly also proposed a change to Ordinance 4 of the Church Order, which would remove any reference to the NHKA as a volkskerk (ethnic church) for the Afrikaners.

It is important to note, that the General Assembly accepted this proposal, but without the sufficient percentage (66\%) to change the Church Order. This represents a significant vote and reflects a changing attitude.

The General Assembly also affirmed its commitment to and good relationship with the Maranatha Reformed Church of Christ (MRCC). A translation of the decision taken by the General Assembly is as follows:

- The General Assembly professes the unity between the NHKA and the MRCC which already exists in Jesus Christ.

- The Assembly is grateful that this unity could be maintained over a period of 80 years and prays that it will become more visible in future.

- The Assembly wishes to support congregations of the NHKA in their missionary witness to the world, in partnership with congregations of the MRCC.

- In obedience to the gospel of Jesus Christ, the Assembly requests the Commission of the General Assembly to continue with a process of structured co-operation, so that the unity that already exists in terms of the churches' confession, theological training, mission work, diaconia, finance and administration can become more visible, with the understanding that the particularities of the two churches will be respected.

- The Commission of the General Assembly receives instruction to re-examine the NHKA's understanding of church unity and the way in which it manifested in the past in relationship with other churches. This includes discussions with the sister churches as well as the MRCC on unity and models of church unity. The Commission will inform the Church on progress and will stimulate debate on this matter.

- The 69th General Assembly will take further decisions on structured co-operation as well as structural unity.

(NHKA 2007:115)

The 68th General Assembly also confirmed the previous General Assembly's decision to apply for observer status at the SACC. This has been granted officially, in writing, by the SACC. The implication of this is that the NHKA is member of all the major ecumenical bodies in South Africa, as well as the REC but not of the WARC. After the 68th General Assembly, the NHKA was informed by the WARC that:

The Executive Committee received a report on how close the NHKA General Assembly came to passing the recommendations that would have made it possible for WARC to readmit the 
NHKA. The Executive Committee received this with much pain, because we looked forward so much to the readmittance of the NHKA. Unfortunately, with this trend of events, the Executive Committee had no other choice but to retain the status quo which is to remain in the state of suspension.

(NHKA 2007b)

During 2009, the WARC Executive paid a visit to the NHKA in Pretoria. This meeting ended in a dead-end street with very little progress. In response to the negative outcome of the discussions between the NHKA General Commission and the WARC delegation, five NHKA theologians (A.G. van Aarde, J. Buitendag, Y. Dreyer, E. van Eck and J.A. Loader made a public announcement in which they rejected Apartheid as contrary to the gospel of Jesus Christ. This resulted in a renewed debate in the NHKA on Apartheid.

In the declaration (see NHKA 2009:16-18) the five professors stated that a moment of truth has presented itself, through the work of the Holy Spirit, to the NHKA. The moment of truth pertains to an unequivocal rejection of Apartheid as contrary to the gospel of Jesus Christ. Therefore, they declare (in translated form) that Apartheid, in practice and essence, is a sin and any theological justification of it a grave error. The declaration continues by discussing the implications of a gospel of love as well as unity and diversity in the church. The declaration ends with a prayer in which the guilt of the church is confessed and an invitation to other ministers to also sign the declaration.

The actions of the five theologians resulted in several congregations sending letters to the General Commission, in which they express their disproval. Formal charges were laid against them. The General Commission attended to the matter and diffused the situation by referring it to the 69th General Assembly (26 September - 02 October 2010). This was done by submitting the same proposal to the 68th General Assembly (NHKA 2010:343-344). In this proposal it is stated that Apartheid is contrary to the gospel of Jesus Christ, based on the idea of human irreconcilability, sanctions injustice and damages the image of God in people.

After intense debate, the proposal was passed as Resolution 54 by a majority of 245 against 173 votes.

The proposal to remove the term volkskerk from the Church Order was also accepted with a majority of votes, but less than $66 \%$.
The joint WARC and the REC Consultation (Grand Rapids 2010) approved a proposal to merge. A new ecumenical body, the World Communion of Reformed Churches, came into existence. The NHKA remained excluded from membership from the newly formed WCRC.

In the next few years, a process of consultation will have to take place between the NHKA and the WCRC to plot a way forward which could end 30 years of international isolation.

\section{References}

Berkhof, H., 1954, 'Evanston', Wending 9(9), 577-578.

Blei, K., 1994, 'Apartheid as a status confessionis', Studies from the World Alliance of Reformed Churches, Volume 25, viewed n.d., from http://www.warc.ch/dcw/ bs25/11.html.

Botha, A.J., 1986, Die evolusie van 'n volksteologie, LWK Drukkery, Bellville.

Botha, S.J. (ed.), 1989, Belydende Volkskerk, Pretoria, Kital.

Dreyer, W.A., 1995, 'Kerk, volk en owerheid - 'n Hervormde Perspektief', unpublished DD-dissertation, University of Pretoria.

Du Plessis, T.A., 1968, 'Jacobus Stuart', in W.J. De Kock (red.), Suid-Afrikaanse Biografiese Woordeboek, I, Tafelberg Uitgewers, Kaapstad.

Giliomee, H., 2004, Die Afrikaners, Tafelberg Uitgewers, Kaapstad.

Murray, A.H., 1962, The political philosophy of JA De Mist, HAUM, Cape Town.

NHKA, 1904, Kerkwet en Bepalings, NHKA Kerkargiewe, Pretoria.

NHKA, 1951, Kerkwet en Bepalings van die Ned. Hervormde Kerk van Afrika, NHKA Kerkargiewe, Pretoria.

NHKA, 1973, Herderlike Skrywe aan die lidmate van die NHKA met betrekking tot vokere verhoudings in die RSA, Akte van Kommisie van die Algement Vergarding, NHKA Kerkargiewe, Pretoria.

NHKA, 1990, Kerk en Politiek, NHKA, Kerk Argiewe Pretoria.

NHKA, 1997, Kerkorde van die Ned. Hervormde Kerk van Afrika, NHKA Kerkargiewe, Pretoria.

NHKA, 2001, Notule van die Algemene Kerkvergadering, NHKA Kerkargiewe, Pretoria. NHKA, 2004, Agenda van die Algemene Kerkvergadering, Kerkargiewe, Pretoria.

NHKA, 2005, Correspondence WARC / NHKA, Acts of the Commission of the General Assembly, NHKA Church Archives, Pretoria.

NHKA, 2006, Correspondence WARC / NHKA, Acts of the Commission of the General Assembly, NHKA Church Archives, Pretoria.

NHKA, 2007, Besluitebundel van die Algemene Kerkvergadering, NHKA Church Archives, Pretoria.

NHKA, 2007b, Correspondence WARC / NHKA, Acts of the Commission of the General Assembly, NHKA Church Archives, Pretoria.

NHKA, 2009, Notule van die Handelinge van die Kommissie van die AKV 4-5 Junie 2009, NHKA Kerkargiewe, Pretoria.

NHKA, 2010, Agenda van die 69e Algemene Kerkvergadering, NHKA Kerkargiewe, Pretoria.

Pont, A.D., 1991, Historiese Agtergronde van ons Kerklike Reg Deel 2, Kital, Pretoria. Van Rensburg A.P.J., 1974, Aspekte van die geskiedenis van Afrika, Pretoria, HAUM.

Van Ruler, A.A., 1958, Heeft het nog zin, van 'Volkskerk' te spreken?, Geschriften betreffende de Orde der Ned.Herv. Kerk, No. 8 H. Wageningen: Veeneman \& Zonen.

Van Wyk, D.J.C., 1978, Volkerevehoudings in Suid-Afrika, HAUM, Pretoria.

Volksraad van die Zuid-Afrikaansche Republiek, Grondwet, SA Archives TVl. No. 3/496. Government Press, Pretoria.

World Alliance of Reformed Churches, 1982, 'Ottawa 1982', viewed n.d., from http:// www.warc.ch/dcw/bs25/03.html 